\begin{tabular}{c|c|c|}
\cline { 2 - 3 } CRITICAL & $\begin{array}{l}\text { Western Ghats } \\
\text { PARTNERSHIP FUND }\end{array}$ & \begin{tabular}{l} 
Special Series \\
\cline { 2 - 3 }
\end{tabular} \\
\hline
\end{tabular}

\title{
ECOLOGY, DISTRIBUTION AND POPULATION STATUS OF ELAEOCARPUS VENUSTUS BEDD. (OXALIDALES: ElAEOCARPACEAE), A THREATENED TREE SPECIES FROM AGASTHIYAMALAI BIOSPHERE RESERVE, SOUTHERN WESTERN GHATS, INDIA
}

\author{
Sheeba J. Irwin ${ }^{1}$, D. Narasimhan ${ }^{2} \&$ V. Madha Suresh ${ }^{3}$ \\ ${ }^{1,2}$ Centre for Floristic Research, Department of Botany, Madras Christian College (Autonomous), Chennai, Tamil Nadu \\ 600059 , India \\ ${ }^{3}$ Department of Geography, University of Madras, Chepauk, Chennai, Tamil Nadu 600005, India \\ ${ }^{1}$ sheebajirwin@gmail.com (corresponding author), ${ }^{2}$ narasimhand@gmail.com, ${ }^{3}$ sureshgeography@gmail.com
}

ISSN

Online 0974-7907

Print 0974-7893

OPEN ACCESS
Abstract: This paper deals with the ecology, population size, status of regeneration, habitat degradation and threat status of Elaeocarpus venustus Bedd. an endemic and threatened tree species restricted to Agasthiyamalai Biosphere Reserve, southern Western Ghats, India. The population sites of this species in the study area were recorded using Global Positioning System and mapped using Arc GIS software. The population of this species is highly fragmented due to anthropogenic activities. The total stem count in all population sites from the study area was carried out to understand the population structure. A total of 181 saplings were recorded from the entire study area of which 180 are from a single site. Nearly $64 \%$ of the stems recorded in this study are mature stems. Poor regeneration was seen in population sites that were highly disturbed. In spite of good adult population, the low number of saplings shows poor germination of seeds and establishment of seedlings.

Keywords: Conservation, Elaeocarpus venustus, endemic, Kanyakumari District, population status, propagation, southern Western Ghats.
The Western Ghats, known for its rich species diversity and endemism, is a chain of mountain ranges stretching ca. $1,600 \mathrm{~km}$ in length that run in a south-north direction parallel to the western coast from Tamil Nadu to Gujarat. The United Nations Educational, Scientific and Cultural Organization (UNESCO) has recognized the Western Ghats as one of the Natural World Heritage sites based on its significant natural habitats (UNESCO 2012). Nayar (1996) recognized eight micro-endemic centers in the Western Ghats among which the Agasthyamalai Region has a greater concentration of endemic species. Gopalan \& Henry (2000) have reported 150 taxa as strict endemics to the Agasthiyamalai region of which 24 are tree taxa. Species belonging to the genera such as Elaeocarpus, Garcinia, Myristica, and Syzygium occur in swamps.

\footnotetext{
DOI: http://dx.doi.org/10.11609/JoTT.03309.4378-84
}

Editor: Merlin Franco, Curtin University, Malaysia.

Date of publication: 26 May 2013 (online \& print)

Manuscript details: Ms \# 03309 | Received 18 August 2012 | Final received 04 March 2013 | Finally accepted 02 May 2013

Citation: Irwin, S.J., D. Narasimhan \& V.M. Suresh(2013). Ecology, distribution and population status of Elaeocarpus venustus Bedd. (Oxalidales: Elaeocarpaceae), a threatened tree species from Agasthiyamalai Biosphere Reserve, southern Western Ghats, India. Journal of Threatened Taxa 5(9): 4378-4384; http://dx.doi. org/10.11609/JoTT.03309.4378-84

Copyright: @ Irwin et al. 2013. Creative Commons Attribution 3.0 Unported License. JoTT allows unrestricted use of this article in any medium, reproduction and distribution by providing adequate credit to the authors and the source of publication.

Funding: Self funded.

Competing Interest: None.

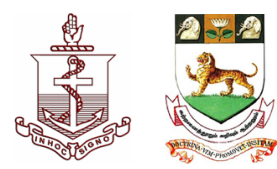

Acknowledgements: We thank Dr. R. Sundaraju IFS, Former Principal Chief Conservator of Forest and Chief Wildlife Warden, Chennai, Dr. R. Annamalai IFS, and Mr. A. Ramkumar IFS, former Field Directors, Kalakkad Mundanthurai Tiger Reserve, Tamil Nadu Forest Department, for granting permission to carry out the study in the Biosphere Reserve

The publication of this article is supported by the Critical Ecosystem Partnership Fund (CEPF), a joint initiative of I'Agence Française de Développement, Conservation International, the European Commission, the Global Environment Facility, the Government of Japan, the MacArthur Foundation and the World Bank. 
Table 1. Distribution pattern of Elaeocarpus species in India

\begin{tabular}{|l|c|c|}
\hline \multicolumn{1}{|c|}{ Region } & $\begin{array}{c}\text { Number } \\
\text { of taxa } \\
\text { recorded }\end{array}$ & $\begin{array}{c}\text { Number of } \\
\text { endemic } \\
\text { taxa }\end{array}$ \\
\hline Northeastern India & 18 & 1 \\
\hline Western Ghats & 16 & 8 \\
\hline Andaman and Nicobar Islands & 8 & 1 \\
\hline Pan India & 8 & 0 \\
\hline
\end{tabular}

The genus Elaeocarpus is distributed in tropical and warm old world regions except Africa. This genus is represented by about 350 species in the world (Mabberley 2008). Thirty three species occur in India of which 10 are endemic (Murthi 1993) (Table 1). Eighty percent of the endemic Elaeocarpus species are confined to the Western Ghats including four steno endemics namely, E. blascoi Weibel, E. gaussenii Weibel, $E$. recurvatus Corner and $E$. venustus Bedd. This paper is a detailed study on the ecology, population size, status of regeneration, habitat degradation and threat status of $E$. venustus Bedd., a narrow endemic and endangered species, restricted to the Agastyamalai Biosphere Reserve (Images 1-3). E. venustus was first collected and described by Beddome (1872) from Muthukuzhivayal.

\section{Materials and Methods}

Study site: The study site is the Western Ghats of Kanyakumari District which is a part of Agastyamalai Biosphere Reserve, India (Fig. 1) that comprises ca. $458 \mathrm{~km}^{2}$ of forests (Chitrapu 1998).

Collection of data and field survey: Data on species distribution was collected from the literature (Chithra 1983; Murthi 1993; Ramesh \& Pascal 1997; Gopalan \& Henry 2000; Zmarzty 2001) and herbaria such as Madras Herbarium (MH), Coimbatore, Tropical Botanic Garden and Research Institute (TBGT), Thiruvananthapuram, and French Institute (HIFP), Pondicherry. Intensive field surveys were carried out for a period of eight years from 2001 to 2009 to locate the places of occurrence of $E$. venustus in Kanyakumari District. Help was also sought from Chandran and Kumar belonging to the Kani tribe and from private estate workers to locate the species.

Population study: Total stem count was carried out for all the population sites recorded. Standard methodology of constructing quadrat was not carried out due to the varying sizes of fragmented patches (0.60-5 ha). Girth at Breast Height (gbh) was taken for all the stems of $E$. venustus. Based on the girth class, populations were grouped into three classes. Stems $<30$ $\mathrm{cm}$ gbh were classified as saplings. Stems between 30

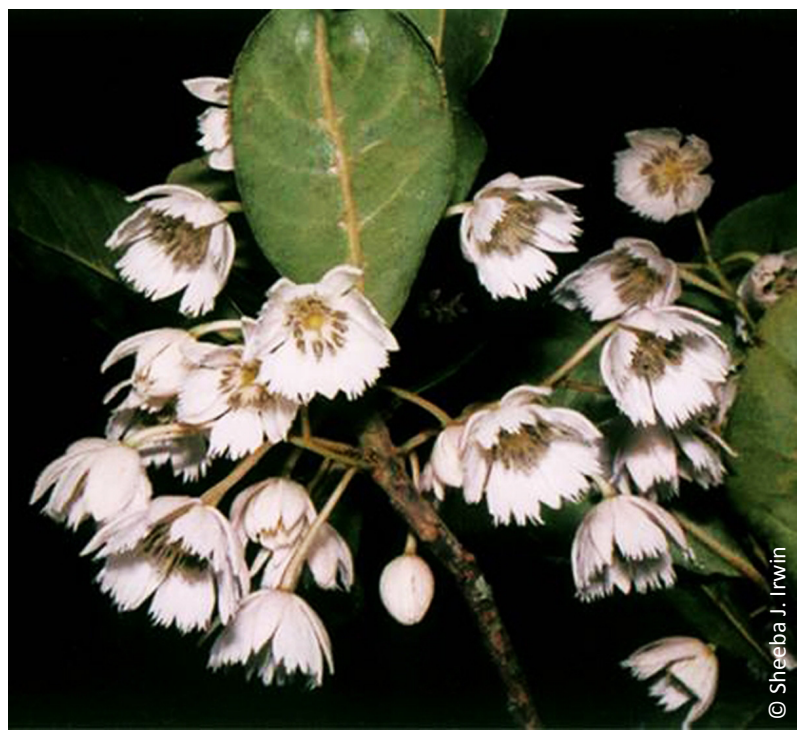

Image 1. Flowering twig of Elaeocarpus venustus

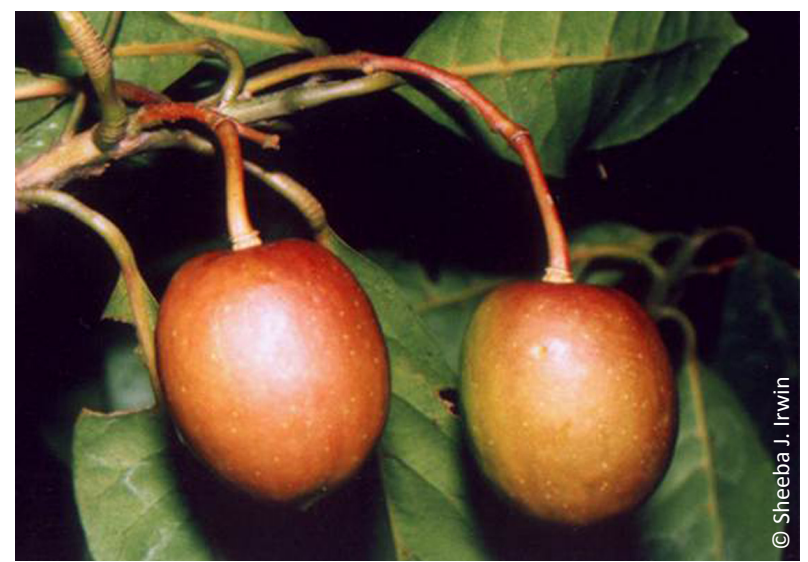

Image 2. Fruits of $E$. venustus

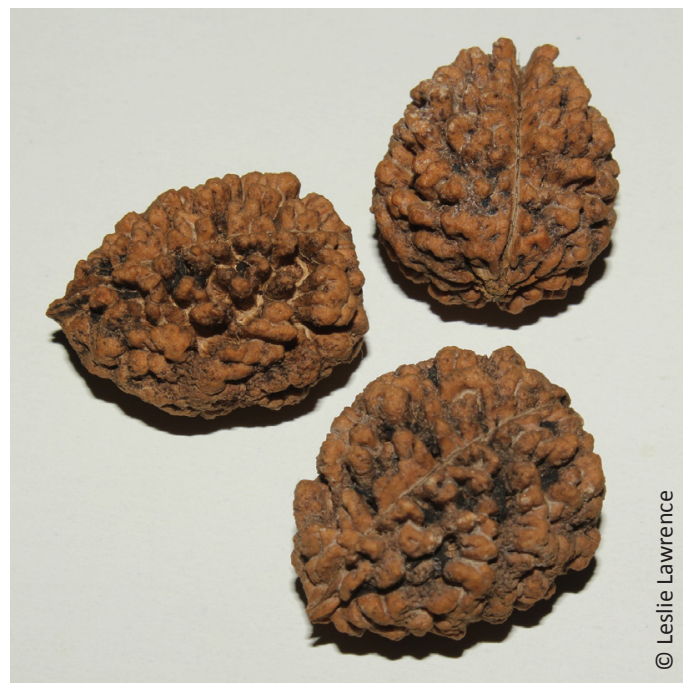

Image 3. Seeds of $E$. venustus 


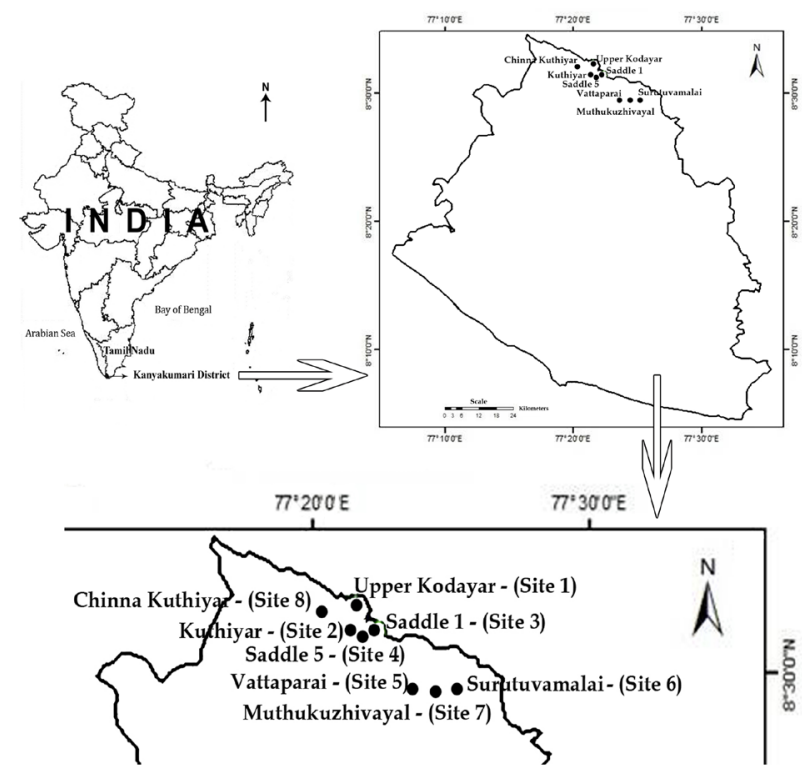

Figure 1. Population sites of Elaeocarpus venustus in Kanyakumari District, Tamil Nadu

$60 \mathrm{~cm}$ gbh were treated as sub adults. Stems $>60 \mathrm{~cm}$ gbh were classified as mature trees.

Adult sapling ratio was calculated to find the rate of saplings transformed to adults. The adult sapling ratio was calculated using the following formula (Ganesan 2001).

Adult sapling ratio $=\frac{\text { Total number of adult stems }}{- \text { Total number of saplings }}$

Mapping: Precise locations of $E$. venustus in Kanyakumari District were mapped using Garmin eTrex Vista Global Positioning System (GPS) handheld receiver. The GPS data were plotted using ArcGIS software and a distribution map was prepared.

\section{Propagation studies}

Seed germination: Seed germination studies were carried out using five different media: sand, cow dung, silt, sand mixed with silt and cow dung and soil from its own habitat. Untreated seeds were used for this study. Seed viability was also tested using Tri phenyl tetrazolium chloride (TTC) (ISTA 1985; Sawma \& Mohler 2002).

Stem cutting: Stem cuttings each measuring about $15 \mathrm{~cm}$ were taken during February-April and JuneAugust from tender, semi-hard and hardwood branches. The control cuttings were dipped in distilled water and others were treated with Indole-Acetic Acid (IAA), IndoleButyric Acid (IBA) and Naphthalene Acetic Acid (NAA) in different concentrations $(200,500,1000,1200,1500$, 2000 and 2500 ppm) for about three hours. Cuttings were then planted in sand mixed with silt.

Air layering: Mature trees were selected for air layering. The bark was girdled $25-30 \mathrm{~cm}$ away from the tip of the branch. The girdles were covered with cotton dipped in IAA, IBA and NAA in different concentrations $(200,500,1000 \mathrm{ppm})$ chosen on the basis of the results obtained from stem cuttings. They were then covered with moss and coconut fibre and sealed by a polythene sheet. Layerings were observed regularly for root initiation.

\section{Results and Discussion}

Distribution: Elaeocarpus venustus is located in eight sites covering an area of about 9 hectares (Table 3). Each site is spaced $3-8 \mathrm{~km}$ apart. This species occupies an area of about $0.089 \mathrm{~km}^{2}$ of the total area of the forest in Kanyakumari District. It is seen growing between 12501500 m exclusively in swamps (Image 4). This species is found growing in association with Aglaia bourdillonii Gamble, Calophyllum austroindicum Kosterm., Cullenia exarillata Robyns, Myristica dactyloides Gaertn., Elaeocarpus munronii (Wight) Mast., E. tuberculatus Roxb., Garcinia travancorica Bedd., G. rubro-echinata Kosterm., Holigarna nigra Bourd., Syzygium mundagam (Bourd.) Chithra and S. rama-varmae (Bourd.) Chithra.

Ecology: Ganesan (2002) classified E. venustus swamps into three types: (1) Open swamps bordered by E. venustus, (2) Swamps with monospecific stand of $E$. venustus, and (3) Mosaics of primary forest vegetation and swampy vegetation. Second and third type of swamps were observed in the study area. Site 7 fits the description of the second type and other sites can be classified under the third type.

Presence of stilt roots, an adaptation to swampy habitat, was observed in most of the trees in the study

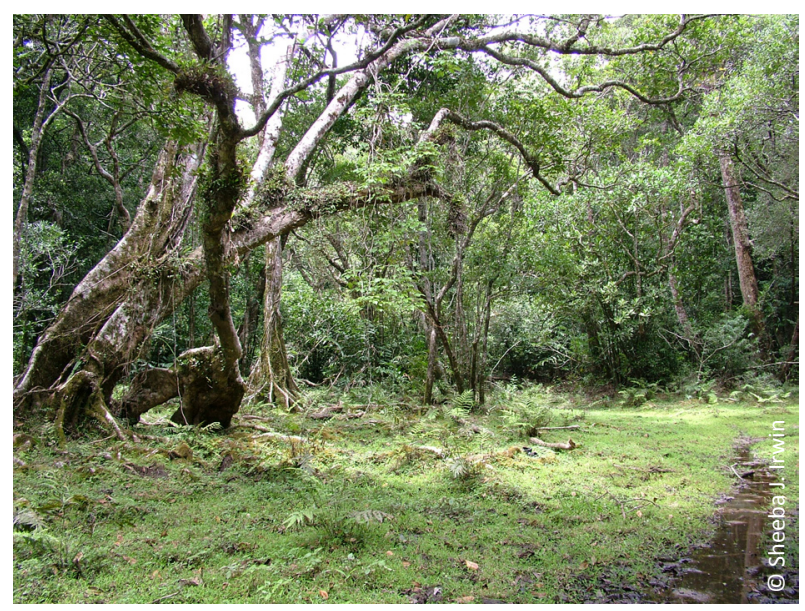

Image 4. Swampy habitat of $E$. venustus 
area. Appearance of basal branches from the trunk close to the ground in clusters was a common phenomenon found in the populations at sites 5 and 7 . Trunks of several trees were observed leaning on the ground and rooting at its base. All these features are attributed to the marshy habitat (Ganesan 2001). Trees above threemeter girth show hollow trunks throughout the study area. Copious flowering alternates with poor flowering.

Population Details: A total of 701 stems of $E$. venustus were recorded of which, 449 were mature stems, 71 were sub-adults and 181 are saplings (Fig. 2). The count was taken during 2009. In general, mature stems were more in number than the saplings. The total number of sub-adults was relatively poor. Fruit setting was relatively good in spite of the irregular flowering frequency. However, a majority of the sites showed poor seed regeneration as evidenced by the low number of saplings.

Habitat Degradation: The forests of Kanyakumari District have undergone severe habitat degradation due to anthropogenic activities. The construction of eight dams for hydroelectric power generation and irrigation is a prime cause for the disappearance of vegetation (Samraj 1998; Sundarapandian et al. 2005) (Table 2). The area cleared for the construction of the dams is more than the area of the existing forests $\left(464 \mathrm{~km}^{2}\right)$. The extant populations are further fragmented by the construction of roads to reach the hydroelectric dams and power stations. Fragmentation is a major cause that severely affects the regeneration, genetic exchange and spread of populations (Benitez-Malvido 1998; Laurance et al. 1998).

Table 2. Major reservoirs in Western Ghats of Kanyakumari District

\begin{tabular}{|c|l|c|l|}
\hline S. No & \multicolumn{1}{|c|}{ Dams } & Area $\left(\mathbf{K m}^{2}\right)$ & \multicolumn{1}{|c|}{ Purpose of construction } \\
\hline 1 & Pechiparai & 207.20 & Irrigation \\
\hline 2 & Perunchani & 160.24 & Irrigation \\
\hline 3 & Kuthiyar & 1.52 & $\begin{array}{l}\text { Hydro - Electric Power \& } \\
\text { Irrigation }\end{array}$ \\
\hline 4 & Upper Kodayar & 29.14 & $\begin{array}{l}\text { Hydro - Electric Power \& } \\
\text { Irrigation }\end{array}$ \\
\hline 5 & Lower Kodayar & 29.14 & $\begin{array}{l}\text { Hydro - Electric Power \& } \\
\text { Irrigation }\end{array}$ \\
\hline 6 & Chittar II & 26.16 & Irrigation \\
\hline 7 & Chittar I & 22.02 & Irrigation \\
\hline 8 & Chinnakuthiyar & 2.59 & $\begin{array}{l}\text { Hydro - Electric Power\& } \\
\text { Irrigation }\end{array}$ \\
\hline
\end{tabular}

Modified from Samraj (1998)

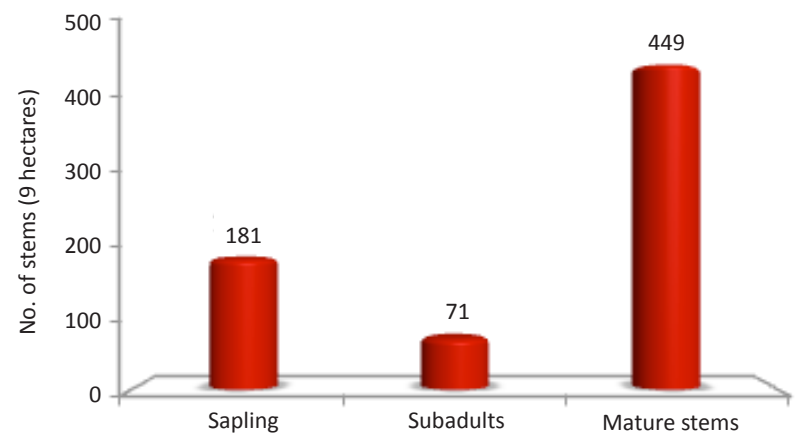

Figure 2. Population Structure of E. venustus in Kanyakumari District

Regeneration versus Habitat Degradation: Adult-sapling ratio is a good indicator of the rate of regeneration. If the ratio is close to or more than one, the population is said to be regenerating well with a large number of saplings being converted into adults (Ganesan 2001). Of the eight sites, four sites (site 1,2,3 $\& 8)$ are highly disturbed due to the construction of dams and roads (Table 3 ). Population sites which were highly disturbed due to anthropogenic interference show very poor regeneration (Table 3 ) and show zero adult-sapling ratio. In sites 6 and 8 only a single stem was recorded. Perhaps, E. venustus is a recent introduction to the swamps of these sites as evidenced by the relatively young stems. Site 5 shows a good population of adults (71 stems) and a lower number of sub-adults (12 stems). Saplings were completely absent at this site. The absence of saplings, in spite of good adult population, indicates poor germination of seeds and establishment of seedlings. The reasons for this phenomenon need to

Table 3. Habitat degradation and adult sapling ratio

\begin{tabular}{|l|l|c|c|}
\hline Name of the Sites & $\begin{array}{l}\text { Nature of site } \\
\text { disturbance }\end{array}$ & $\begin{array}{c}\text { Type of } \\
\text { disturbance }\end{array}$ & $\begin{array}{c}\text { Adult sapling } \\
\text { ratio }\end{array}$ \\
\hline $\begin{array}{l}\text { Site } 1 \text { (Upper } \\
\text { Kodayar) }\end{array}$ & $\begin{array}{l}\text { Highly } \\
\text { disturbed }\end{array}$ & Road & 0 \\
\hline Site 2 (Kuthiyar) & $\begin{array}{l}\text { Highly } \\
\text { disturbed }\end{array}$ & Dam \& Road & 0 \\
\hline Site 3 (Saddle 1) & $\begin{array}{l}\text { Highly } \\
\text { disturbed }\end{array}$ & Dam & 0 \\
\hline Site 4 (Saddle 5) & $\begin{array}{l}\text { Less } \\
\text { disturbed }\end{array}$ & Dam & 0 \\
\hline Site 5 (Vattaparai) & $\begin{array}{l}\text { Less } \\
\text { disturbed }\end{array}$ & - & 0 \\
\hline $\begin{array}{l}\text { Site 6 } \\
\text { (Surutuvamalai) }\end{array}$ & $\begin{array}{l}\text { Less } \\
\text { disturbed }\end{array}$ & $\begin{array}{l}\text { Less } \\
\text { disturbed }\end{array}$ & \begin{tabular}{l}
0 \\
\hline $\begin{array}{l}\text { Site 7 } \\
\text { (Muthukuzhivayal) }\end{array}$
\end{tabular} \\
\hline $\begin{array}{l}\text { Site 8 } \\
\text { (Chinnakuthiyar) }\end{array}$ & $\begin{array}{l}\text { Highly } \\
\text { disturbed }\end{array}$ & Dam \& Road & 0 \\
\hline
\end{tabular}


be explored through more intensive field studies.

Only Site 7 showed a better adult-sapling ratio (1.3). Site 7 has a monospecific strand of $E$. venustus that can be recognized as a flagship species of this area. Of the 181 saplings recorded from the entire district 180 occurred at this site. This site was once a heavily disturbed site that was cleared for planting cardamom during the 1870s (Jacob 1917). However, the plantations were abandoned about two decades ago. Occurrence of more saplings in this site proves that if an area is left undisturbed, regeneration of native species is promoted naturally, especially of endemic species. On the other hand, occurrence of more saplings may be due to the high rate of seed germination. Clearing the forests in this site, for cardamom plantations, could have paved the way for more light thus enhancing seed germination. Similar observations have been made for a number of endemic species in tropical forests (Baskin \& Baskin 1998; Ganesan 2001; Ganesan et al. 2001; Castellanos \& Stevenson 2011). There has been little anthropogenic interference in this region after declaring it as a biosphere reserve in 2005 (MoEF 2012).

Seed germination and vegetative propagation: Fifty seeds randomly drawn from different populations were tested for viability and $100 \%$ viability was observed. About $1 \%$ of the seeds were found to be infected by stem borer. A set of 200 viable untreated seeds were sown in different media to study the rate of germination. Seeds started to germinate after 75 days. Germination of $40 \%$ was observed in silt mixed in sand and about $8 \%$ in sand mixed with silt and cow dung. Seeds sown in other media did not germinate. However, a study by Saravanan et al. (2011) stated that E. venustus showed $0 \%$ germination in spite of various treatments.

IBA was the most effective hormone in initiating roots. IBA (1000 ppm) produced rooting in $90 \%$ of the stem cuttings whereas, NAA in the same concentration produced only in $10 \%$ of cuttings. Rooting was $100 \%$ for air layering in 1000 ppm of IBA (Image 5) when compared to the $16 \%$ success as reported by Saravanan et al. ( 2011).

A few plantlets raised through cuttings were planted in the premise of a few private estates within the biosphere reserve for close monitoring and safety from wild animals some of which have shown remarkable establishment. Image 6 shows a five year old $E$. venustus growing in a private estate in Kanyakumari District which has attained a girth of $30 \mathrm{~cm}$.

Conservation measures: $E$. venustus is confined to a swampy habitat which is a specialized ecological niche and is assessed as Vulnerable in the IUCN Red List of

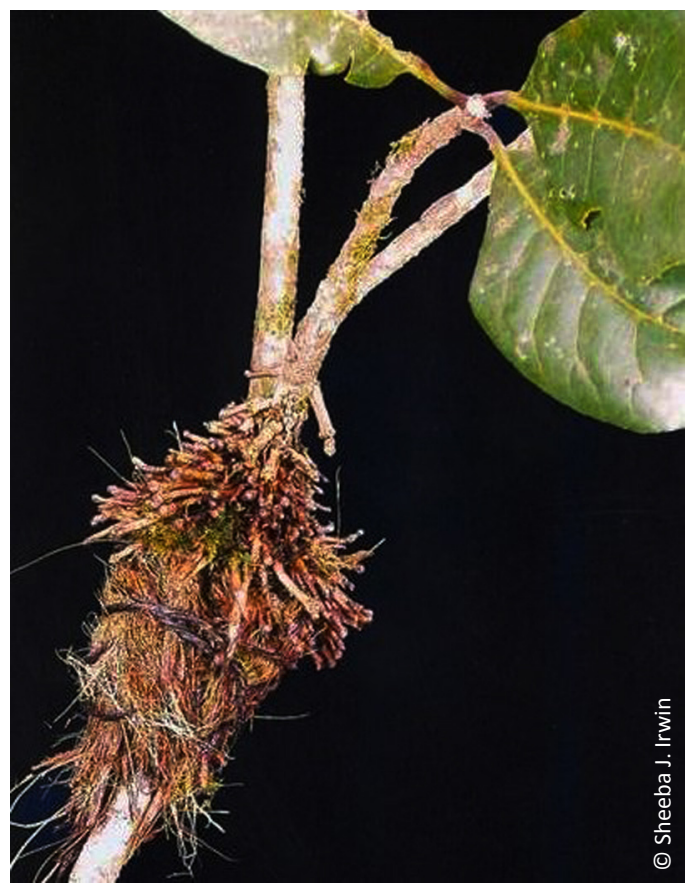

Image 5. Air-layered twig

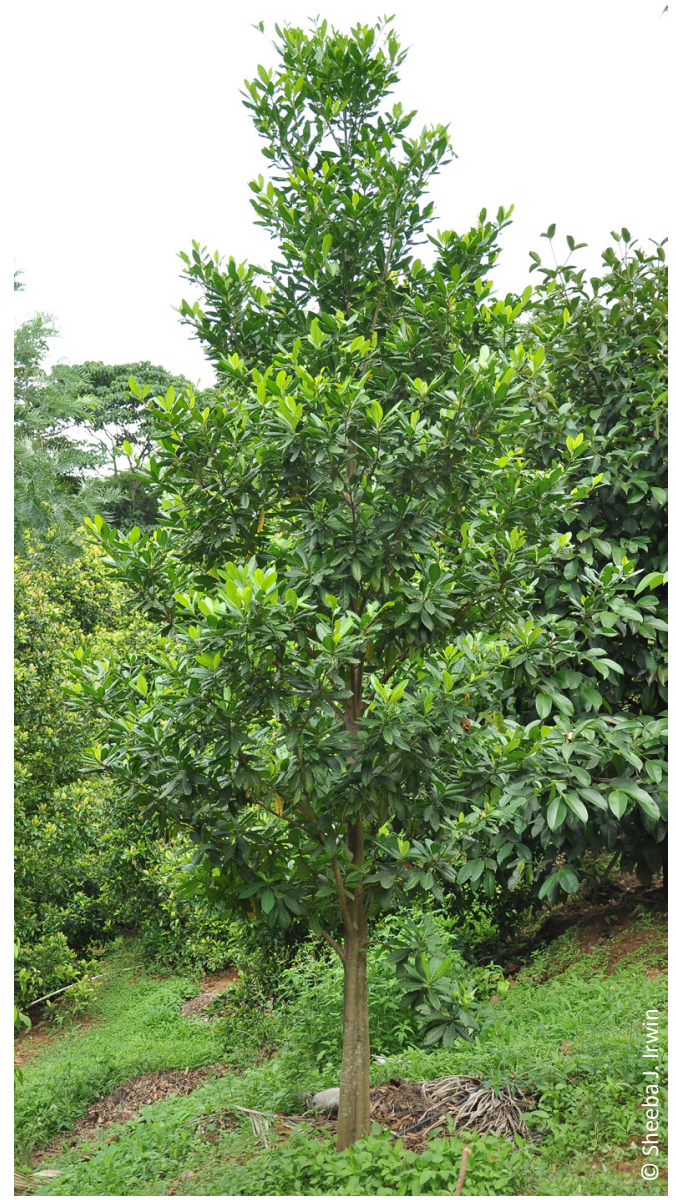

Image 6. A five year old E. venustus growing in an ex situ habitat 
Threatened Species (WCMC 1998). Endemic species which are confined to a particular ecological region, once lost, will be a great loss to the biodiversity forever. Hence, conservation priority should be given to these endemic species (Raven 1988; Nayar 1997). Agasthyamalai and its environs have been affected by the conversion of the reserve forests into plantations, reservoirs and roads which is a severe threat to the species (Gadgil \& Meher-Homji 1986; Pascal 1990; Bawa \& Dayanandan 1998; Menon et al. 2001). Ramesh et al. (1997) suggest that fragmented populations of endemic species need continuous monitoring for better conservation and management. A long term study is required as E. venestus show poor seed germination, poor fruit dispersal as well as requires specialized environment for germination, as emphasized for all tropical tree species (Ashton 1969, 1981; Gomez-Pompa et al. 1972; Bawa 1974). Given that the previous assessment by the IUCN Red List was in 1998 and the ongoing threats impacting negatively on the habitat, the species may even be more highly threatened. Its current status must be assessed immediately and suitalbe conservation action mooted.

\section{REFERENCES}

Ashton, P.S. (1969). Speciation among tropical forest trees: Some deductions in the light of recent evidence. Biological Journal of the Linnean Society 1: 155-196; http://www.dx.doi. org/10.1111/j.1095-8312.1969.tb01818.x

Ashton, P.S. (1981). Techniques for the identification and conservation of threatened species in tropical forests, pp. 155-164. In: Synge, H. (ed.). The Biological Aspects of Rare Plant Conservation. Wiley Inter Science, New York, 586pp.

Bawa, K.S. (1974). Breeding systems of tree species of a lowland tropical community. Evolution 28: 85-92.

Bawa, K.S. \& S. Dayanandan (1998). Causes of tropical deforestation and institutional constrains to conservation, pp. 175-195. In Goldsmith, F.B. (ed.). Tropical Rain Forest: A Wider Perspective. Chapman \& Hall, London, 437pp.

Beddome, R.H. (1872). The Flora Sylvatica for Southern India. Gantz Brothers, Madras, 204pp.

Benitez-Malvido, J. (1998) Impact of Forest Fragmentation on Seedling Abundance in a Tropical Rain Forest, Conservation Biology 12: 380389; http://www.dx.doi.org/10.1111/j.1523-1739.1998.96295.x

Baskin, C.C. \& J.M. Baskin (1998). Seeds: ecology, biogeography, and evolution of dormancy and germination. Academic Press, London, 666pp.

Castellanos, M.C. \& P.R. Stevenson (2011). Phenology, seed dispersal and difficulties in natural recruitment of the canopy tree Pachiraquinata (Malvaceae). Revista de Biologia Tropical (International Journal of Tropical Biology and Conservation) 59(2): 921-933.

Chithra, V. (1983). Elaeocarpaceae, pp. 46-47. In: Nair, N.C. \& A.H. Henry (eds.). Flora of Tamil Nadu. 1. Botanical Survey of India, Coimbatore, $184 \mathrm{pp}$.

Chitrapu, V.R. (1998). Kanyakumari District and its Natural Heritage. Zoos' Print 13(2): 3-4.

Gadgil, M. \& V.M. Meher-Homji (1986). Role of protected areas in conservation, pp. 143-159. In: Chopra V.L. \& T.N. Khoshoo (eds.). Conservation of Productive, Agriculture, Indian Council of Agricultural Research, New Delhi, 173pp.

Ganesan, R. (2001). Tree diversity and regeneration in logged wet evergreen forests of the Agasthyamalai range in South Western Ghats, India. PhD Thesis. University of Madras.

Ganesan, R. (2002). Evergreen forest swamps and their plant species diversity in Kalakad-Mundanthurai Tiger Reserve, South Western Ghats, India. Indian Forester 128(12): 1351-1359.

Ganesan, R., T. Ganesh, M.S. Devy \& P. Davidar (2001). Regeneration dynamics of a wet evergreen forest, Southern Western Ghats, India, pp. 231-234. In: Ganeshaiah, K.N., R.U. Shaanker \& K.S. Bawa (eds.). Tropical Ecosystems: Structure, Diversity and Human Welfare, Oxford - IBH, New Delhi, 792pp.

Gomez-Pompa, A., G. Vazquez-Yanes \& S. Guevara (1972). The Tropical Rain Forest: A non renewable resource. Science 177: 762-765.

Gopalan, R. \& A.N. Henry (2000). Endemic Plants of India. Camp for the strict endemics of Agasthiyamalai hills, SW. Ghats. Bishen Singh Mahendra Pal Singh, Dehradun, 476pp.

ISTA (International Seed Testing Association) (1985). International rules for seed testing. Seed Science Technology 13:300-520.

Jacob (1917). Working Plan Report of The Palode and the Veerapuli Working Circles. Travancore Government, Travancore, 136pp.

Laurance, W.F., L.V. Ferreira, J.M. Rankin-De Merona, S.G. Laurance, R.W. Hutchings and T.E. Lovejoy (1998). Effects of Forest Fragmentation on Recruitment Patterns in Amazonian Tree Communities. Conservation Biology 12(2): 460-464; http://www. dx.doi.org/10.1111/j.1523-1739.1998.97175.x

Mabberley, D.J. (2008). Mabberley's Plant-Book, A portable dictionary of plants, their classification and uses. Cambridge University Press, United Kingdom, 1040pp.

Menon, S., K.S. Bawa, K.N. Ganeshaiah \& R.U. Shaanker (2001). Landuse change and conservation priorities in the Western Ghats, pp. 549-551. In: Ganeshaiah, K.N., R.U. Shaanker \& K.S. Bawa (eds.) Tropical Ecosystems: Structure, Diversity and Human Welfare. Oxford-IBH, New Delhi, 792pp.

MoEF (2012). List of Biosphere Reserves, their area, date of designation and its location, <http://moef.nic.in/divisions/csurv/brs-list.pdf> Downloaded on 16 July 2012.

Murthi, S.K. (1993). Elaeocarpaceae, pp. 529-562. In: Sharma, B.D. \& M. Sanjappa (eds.). F1ora of India 3: 562. Botanical Survey of India, Calcutta, 639pp.

Nayar, M.P. (1996). "Hot Spots" of Endemic Plants of India, Nepal and Bhutan. Tropical Botanic Garden and Research Institute, Palode, Thiruvananthapuram, 252pp.

Nayar, M.P. (1997). Conservation of rare and endangered species of Indian flora: strategies for botanical gardens, pp 47-57. In: Pushpangadan, P., K. Ravi \& V. Santhosh (eds.). Conservation and Economic Evaluation of Biodiversity - Vol. 1. Oxford \& IBH, Calcutta, 694pp.

Pascal, J.P. (1990). Floristic composition and distribution of evergreen forests in the Western Ghats, India. The Palaeobotanist 39(1): 110126.

Ramesh, B.R. \& J.P. Pascal (1997). Atlas of Endemics of the Western Ghats (India): Distribution of tree species in the evergreen and semievergreen forests. Institute Francais de Pondichery, Pondicherry, 403pp.

Ramesh, B.R., S. Menon \& K.S. Bawa (1997). A Vegetation Based Approach to Biodiversity Gap Analysis in the Agastyamalai Region, Western Ghats, India. Ambio 26(8): 529-536.

Raven, P.H. (1988). Tropical Floristics Tomorrow. Taxon 37(3): 549560.

Samraj, P. (1998). Impact of major reservoirs in Kanyakumari District of Tamil Nadu on the wild life. Zoos' Print 13(2): 19-21.

Saravanan, S., Indra, M., Kamalraj, D.R., Venkatesh \& Muthuchelian, K. (2011). In-situ vegetative propagation of Elaeocarpus venustus Bedd. a threatened endemic tree of Agasthiamalai Biosphere Reserve, Western Ghats, India. Journal of Bioscience Research 2(2): 46-49.

Sundarapandian, S.M., S. Chandrasekaran \& P.S. Swamy (2005). 
Phenological behaviour of selected tree species in tropical forests at Kodayar in the Western Ghats, Tamil Nadu, India. Current Science 88(5): 805-810.

Sawma, J.T. \& C.L. Mohler (2002). Evaluating Seed Viability by an Unimbibed Seed Crush Test in Comparison with the Tetrazolium Test. Weed Technology 16(4): 781-786.

UNESCO (2012). Western Ghats. <http://whc.unesco.org/en/ list/1342>. Downloaded on 25 July 2012.

World Conservation Monitoring Centre (WCMC) (1998). Elaeocarpus venustus. In: IUCN 2012. IUCN Red List of Threatened Species. Version 2012.2. <www.iucnredlist.org>. Downloaded on 08 May 2013.

Zmarzty, S. (2001). Revision of Elaeocarpus (Elaeocarpaceae) section Elaeocarpus in Southern India and Sri Lanka. Kew Bulletin 56: 405447. 